\title{
Elżbieta Smułkowa, Moje pogranicza w historii, języku i wspomnieniach, Slawistyczny Ośrodek Wydawniczy, Instytut Slawistyki PAN, Warszawa 2016, ss. 447
}

Wydawanie książek gromadzących rozproszony publikacyjnie dorobek (lub jego fragment, dobrany pod względem tematyczno-problemowym lub chronologicznym) jednego uczonego jest bezsprzecznie ważne i wartościowe. Taka też ważka dla nauki polskiej jest publikacja Moje pogranicza w historii, języku $i$ wspomnieniach Elżbiety Smułkowej. W rozdziale trzecim (Pamięć osób i miasta) Autorka wypowiada się w tej kwestii w sposób następujący: „Wiem $\mathrm{z}$ doświadczenia, że dopiero zebranie artykułów drukowanych w różnych czasopismach $\mathrm{w}$ jednej książce zapewnia im odpowiedni obieg naukowy. W przeciwnym przypadku na ogół idą w zapomnienie i często następne pokolenia badaczy nie wiedzą lub nie chcą wiedzieć o ich istnieniu" (s. 306).

Słowami tymi badaczka uzasadnia postulat wydania dwutomowego wyboru prac naukowych zmarłej w 2011 roku toruńskiej lingwistki Teresy Friedelówny. Sąd jest niewątpliwie słuszny, choć akurat w wypadku rozproszonych po różnych czasopismach i książkach zbiorowych prac Elżbiety Smułkowej w żadnym wypadku nie wchodzi w grę ich zapomnienie: każda jej publikacja (a także każdy referat na konferencji naukowej) była i jest naukowym wydarzeniem. Niemniej jednak zebranie takich prac $\mathrm{w}$ jednej książce wydatnie ułatwi z nimi kontakt i potęguje ich oddziaływanie na środowisko językoznawcze.

Trzeba stwierdzić, że ranga i rola takich zbiorczych książek jest wprost proporcjonalna do wartości zawartych w nich przedruków. Innymi słowy: im wybitniejszy uczony, tym bardziej zasadne, przydatne i pożyteczne zebranie jego prac $\mathrm{w}$ jednym miejscu. W naszym wypadku mamy więc do czynienia z najwyższym stopniem zasadności, przydatności i pożytku, 
gdyż Elżbieta Smułkowa należy do najściślejszej czołówki polskich językoznawców-slawistów.

W recenzji autorstwa Bogdana Walczaka umieszczonej na okładce książki Elżbiety Smułkowej czytamy: „Jest uczoną, która - co wcale nie takie częste - łączy kompetencje i doświadczenia doskonałego eksploratora-terenowca z doniosłymi koncepcjami teoretycznymi i metodologicznymi, solidną i gruntowną wiedzę dialektologiczną i socjolingwistyczną z rozległą erudycją i głęboką wrażliwością ogólnohumanistyczną, wreszcie naukowy profesjonalizm ze świadomością pozanaukowych, społecznych (a czasem nawet politycznych) zadań i obowiązków slawisty-znawcy złożonej problematyki Europy Środkowej i Wschodniej”. Niezwykłe bogactwo osobowości twórczej Elżbiety Smułkowej znajduje odzwierciedlenie w omawianej książce.

W pierwszej części tomu (Biatoruś $i$ inne tematy) przeważają prace relacjonujące współczesną sytuację językową i społeczną Białorusi i polską (nie)znajomość złożonej problematyki tego kraju. W części drugiej (Mowa mieszkańców pogranicza białorusko-polsko-litewskiego) przeważają bardzo ważne naukowo, odkrywcze koncepcje teoretyczno-metodologiczne, stanowiące doniosły wkład Autorki do teorii kontaktów językowych (uwagi o metodologii badań pograniczy językowych, o istocie i statusie gwar przejściowych i mieszanych, o współczesnej konwergencji językowej jako wyniku wielowiekowych kontaktów językowych, skutkujących wzajemnymi interferencjami i zapożyczeniami), wreszcie w części trzeciej (Pamięci osób i miasta) ważne wspomnienia o mistrzyni naukowej Elżbiety Smułkowej - Antoninie Obrębskiej-Jabłońskiej i o przyjaciołach: Teresie Friedelównie, Walerym Czekmanie i Adamie Maldzisie, a także o ojcu, leśniku (na wysokim stanowisku w służbie leśnej), zamordowanym przez stalinowskich oprawców w 1940 roku i pochowanym na cmentarzu w Bykowni, i stryju, znanym literacie i teatrologu Tymonie Terleckim.

W tej części omawianego tomu Autorka dokonała przedruku fragmentów swojej książki wspomnieniowej Byt dom we Lwowie z roku 2013. Jak sama Elżbieta Smułkowa tłumaczy w Streszczeniu poprzedzającym przedruk fragmentów książki: „Czytelnik znajdzie tu wiele udokumentowanych faktów i przekazów wspomnieniowych naocznych świadków prac nad zachowaniem polskiego poczucia narodowego, dóbr polskiej kultury, wiary chrześcijańskiej i cmentarzy oraz zorganizowanej opieki medycznej nad wielorakimi potrzebującymi” (s. 345); wskazuje jednocześnie, iż głównymi bohaterkami książki są: Irena Pelczarska, Maria Skierska i Janina Sosabowska.

Całość książki badaczki zamykają: obszerna Bibliografia, dalej Bibliografia prac Elżbiety Smulkowej za lata 2002-2016, Wykaz pierwodruków publikacji Elżbiety Smulkowej zamieszczonych w książce oraz Spis ilustracji. 
Wydanie książki Elżbiety Smułkowej Moje pogranicza w historii, języku $i$ wspomnieniach jest bezspornie pożyteczne, przydatne i konieczne.

W kwestiach merytorycznych nieliczne szczegóły przykuwają uwagę. Na s. 35 omawianej książki (w artykule Moje widzenie Białorusi) znajdujemy informację, że ,funkcję języka pisanego, w tym kancelaryjnego, w Wielkim Księstwie Litewskim do mniej więcej połowy XVII wieku pełnił język wywodzący się $\mathrm{z}$ tradycji piśmiennictwa staro-cerkiewno-słowiańskiego, stosujący alfabet cyrylicki i w mniejszym lub większym stopniu wyuczone staro-cerkiewno-słowiańskie zasady pisowni”. I choć w dalszej części artykułu Autorka dodaje: „oficjalną datę zakazu ruskiego języka kancelaryjnego (1698/1697) [Walczak 2012: 198-199 i prace wcześniejsze] traktuję za Arkadiuszem Żurauskim [Жураўскі 1967: 354] jako formalne, prawne usankcjonowanie stanu rzeczy, który dokonał się faktycznie wcześniej [Smułkowa 1988]" (s. 36), warto przypomnieć wyjaśnienia Bogdana Walczaka [Z polskich studiów slawistycznych, seria 12, Warszawa 2012, s. 195-202]. Język ruski (starobiałoruski, z elementami cerkiewnymi, a później też polskimi) jako kancelaryjny język Wielkiego Księstwa Litewskiego był językiem państwowym Wielkiego Księstwa nie „mniej więcej do połowy” (jak sugeruje Elżbieta Smułkowa), lecz do końca XVII wieku - zmiana języka państwowego miała miejsce dopiero w ostatnich latach stulecia. W 1697 roku, w ramach tzw. koekwacji praw (czyli usuwania, a raczej ograniczania różnic prawnych między Litwą a Koroną) w czasie bezkrólewia po śmierci Jana III, na mocy suwerennych ustaw litewskich sejmików, językiem państwowym została, jak w Koronie, polszczyzna. Oczywiście górne warstwy społeczeństwa ruskiego - i wcześniej już zrutenizowane górne warstwy litewskie - zaczęły się polszczyć już w XV wieku i można zasadnie przyjąć, że w 2. połowie XVII stulecia pierwszym językiem ruskiej (a także pierwotnie litewskiej, jak np. Radziwiłłowie) z pochodzenia magnaterii i bogatej oraz średniej (miejscami nawet uboższej) szlachty Wielkiego Księstwa był już język polski, niemniej jednak oficjalna zmiana języka państwowego na Litwie nastąpiła w roku 1697.

W rozdziale zatytułowanym Problem zapożyczeń $w$ warunkach rozpadającej się wielojęzyczności społecznej. Rozważania wstępne (s. 216) Elżbieta Smułkowa podaje jako hiperyzmy na tle wymowy akającej przykłady: opteka 'apteka', sołata 'sałata' i mšo 'msza'. I o ile dwa pierwsze przykłady są właściwe, trzeci wydaje się chybiony. Jednosylabowy (a więc $\mathrm{z}$ akcentowaną samogłoską) wyraz msza trudno chyba rozumieć jako rezultat akania, gdyż w tekstach staropolskich wykazuje $a$ pochylone jako kontynuant pierwotnej długości, tak samo długość kontynuowana jest w bierniku w postaci nosówki tylnej -a (-om - -óm), a w gwarach występuje forma z kontynuacją a pochylo- 
nego. O ile więc opteka i sołata to niewątpliwe hiperyzmy, mšo byłaby raczej archaizmem.

Na zakończenie powtórzę przekonanie, iż publikacja Elżbiety Smułkowej Moje pogranicza w historii, języku i wspomnieniach jest pod każdym względem wartościowa i potrzebna. Prace wybitnej slawistki i humanistki dotąd rozproszone $\mathrm{w}$ różnych czasopismach i książkach zbiorowych zasadnie zostały zebrane i wydane w jednym tomie.

Magdalena Gawrońska-Garstka 